\title{
David Whitehouse
}

The career of David Whitehouse (15 October 1941 17 February 2013) probably spanned a greater range than that of any archaeologist I have known. He excavated in Britain, Italy, Iran, Libya, Afghanistan and Lebanon, held prestigious directorial posts from Kabul to Corning, curated numerous exhibitions, hosted and attended innumerable conferences and had an output of some five hundred or so scholarly publications.

After graduating from Cambridge, David specialised in the archaeology of medieval Italy. Shortly afterwards he was invited to direct the excavations of the early Islamic port site of Siraf on the Persian Gulf on behalf of the then fledgling British Institute of Persian Studies, carrying out seven seasons between 1966 and 1973. These remain the biggest excavations that the Institute has carried out, and one of the most important in Islamic archaeology (and perhaps the last of the 'great digs' in Near Eastern archaeology: specially built dig-house, seasons up to three months, staff up to twenty, and workmen numbering nearly 150 at its peak). While excavating Siraf he also found time to direct three seasons at the early Islamic site of Ajdabiyah in Libya. On completion of the excavations at Siraf he was appointed the first director of the new British Institute of Afghan Studies in Kabul, directing the Institute's first season of excavations at Kandahar and establishing the Institute on a firm footing. In 1974 he returned to Italian medieval archaeology, succeeding John Ward-Perkins as Director of the British School at Rome following his retirement after nearly thirty years there. After ten years in Rome, David moved to the United States to take up a post at the Corning Museum of Glass, becoming its director and remaining in post for the rest of his life. In Corning he is credited with doubling the museum's collection and its transformation into one of the major centres of the study and science of glass making in the world. While devoting the rest of his life to Corning and glass studies, he did not forget his former areas, continuing to write about Afghan, Islamic and Italian medieval archaeology. He even returned to Near Eastern fieldwork briefly when he carried out a short excavation at Tyre in Lebanon in 2000.

In Libya David directed three seasons of excavations at the important Fatimid site of Ajdabiyah, one of only two early Islamic sites examined in any detail in Libya (the other being Medina Sultan). After a preliminary season in 1971, the first full season was in 1972 with a team of nine. During this time and the subsequent briefer season in 1973 the mosque, first

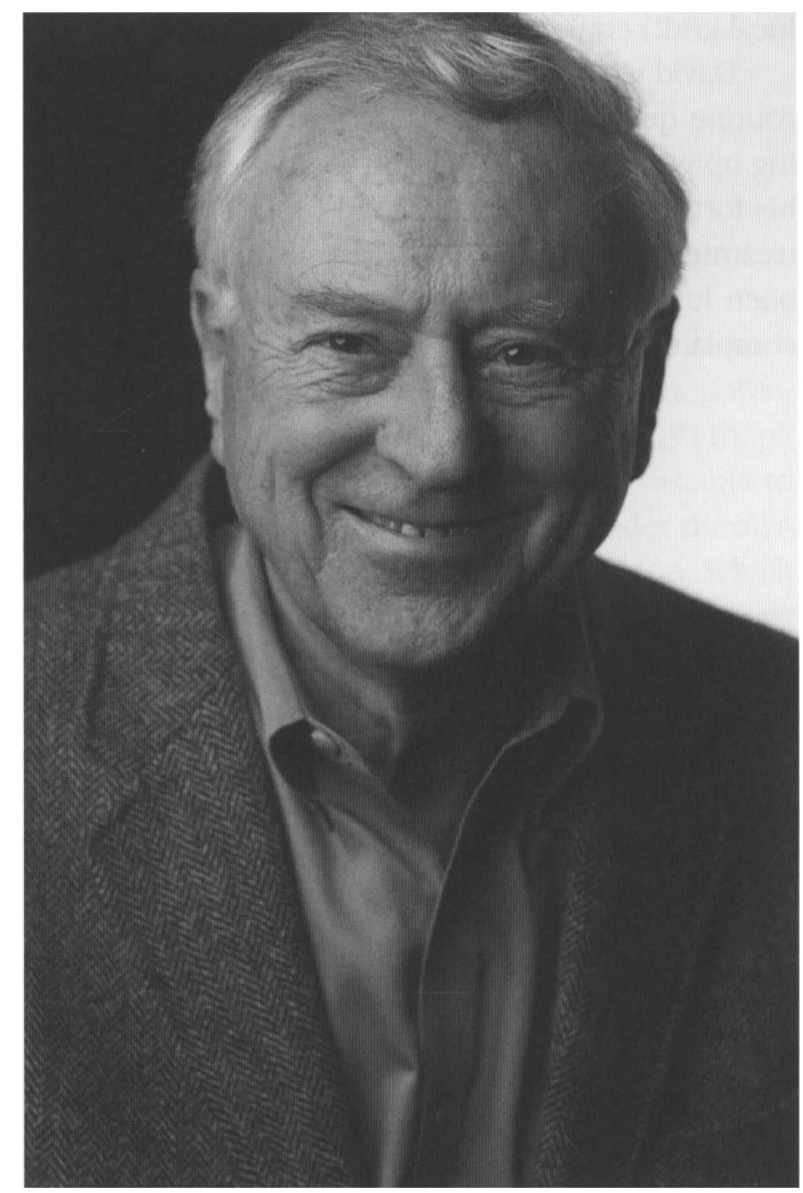

David Whitehouse (photo courtesy of the Corning Museum of Glass).

partially cleared by Richard Goodchild, was completely excavated and recorded. A detailed architectural record was also made of the more substantial remains of Ajdabiyah's fortress-palace, the best preserved of the string of such palaces probably built to mark the triumphal progression of the Fatimid Caliph al-Mu'izz from al-Mahdiya to Cairo. Architectural surveys were also made of the early Islamic sites of Sidi Sahabi near Jalu in Cyrenaica and Qasr al-Hammam near Leptis Magna.

Conditions of work at Ajdabiyah could be trying. My diary for the first day of the 1972 season notes that 'Ajdabiyah is a ... small town, totally undistinguished except for a superb crenellated, ex-Italian governor's residence in atrocious taste. Also a small suq and three cinemas. ... The dig house is completely new, with three bathrooms, none of which have water. No electricity either, despite all mod cons and fittings. ... The dunes are already beginning to build up outside our front wall.' Indeed, the sandstorms - the notorious Libyan gbibli, a characteristic of the Libyan 


\section{OBITUARIES}

Desert in March - and other discomforts could seriously impede the work, even closing down work on occasion, when Ajdabiyah's cinemas (on a different local grid!) could provide welcome distraction.

David wrote to me in October 2012 concerning a routine question about Ghaznavid glass, but following up with the news 'straight from the Dark Side' of his forthcoming demise: 'three to four months with treatment. ... Tant pis. Almost all my breaks have been lucky ones. This is the first lousy one. I can't complain.'
Shortly afterwards he died of cancer in February 2014, age 71. My own first break was certainly a very lucky one when David accepted me - young, inexperienced, wet behind the ears and fresh out of Australia - on the Siraf team, launching my own archaeological career. Of impeccable professional integrity, immense breadth of knowledge and experience - as well as characteristic wit! - all modestly borne, David will be greatly missed.

Warwick Ball 